\title{
Understanding the Concept of Life Process in Animals Based on 7E Inquiry Model through Lesson Study Approach
}

\section{Zanaton H. Iksan, Nuraini Abu Bakar, Aini Haziah Amirullah, Sayyidah Nusaibah Mohd Salehudin}

Faculty of Education, Universiti Kebangsaan Malaysia, Bangi, Malaysia

Email: zanaton.iksan@ukm.edu.my

How to cite this paper: Iksan, Z. H., Bakar, N. A., Amirullah, A. H., \& Salehudin, S. N. M. (2018). Understanding the Concept of Life Process in Animals Based on 7E Inquiry Model through Lesson Study Approach. Creative Education, 9, 1763-1774. https://doi.org/10.4236/ce.2018.911128

Received: July 16, 2018

Accepted: August 28, 2018

Published: August 31, 2018

Copyright $\odot 2018$ by authors and Scientific Research Publishing Inc. This work is licensed under the Creative Commons Attribution International License (CC BY 4.0).

http://creativecommons.org/licenses/by/4.0/

c) (i) Open Access

\begin{abstract}
Inquiry approach is important to improve understanding of science concept. In order to look at the effectiveness of inquiry based learning, Lesson Study approach was employed. This study used 7E inquiry learning model to teach Year 5 students about life process in animal topic. The open lesson was observed by fellow educators and academicians. From the result of observation and reflection, there found a few features of inquiry that was conducted by students during the learning process such as: 1) making an observation, 2) engage in questioning, 3) obtain and use relevant information, 4) propose answers, description or anticipations about a situation, 5) communications, 6) lower-order thinking skills (LOTS), and 7) higher order thinking skills (HOTS). This study implied that lesson study approach helps teachers plan how to integrate the inquiry in their teaching while the implementation can be further revaluated by other teachers to improve inquiry-based lesson so that it could be carried out successfully in the context of students' learning.
\end{abstract}

\section{Keywords}

Inquiry-Based Science Learning, Learning Development, 7E Learning Model, Lesson Study

\section{Introduction}

The lifestyles of today's societies are increasingly influenced by changes in science and technology. Various new findings in science and technology can change the social, ethical, political and economic structures of a country. The statuses of developed and wealthy nations are no longer referred to the abun- 
dance of natural resources, but are seen in their human resources capability to produce various innovations and solutions in the field of science and technology. In response to this challenge, the introduction of scientific knowledge and culture among general public is very important (Kementerian Sains Teknologidan Inovasi, 2010).

As a competitive nation, Malaysia is also striving to be on a par with other developed countries. Therefore, there is an urgent need to provide human capital with a high degree of scientific literacy (Adnan et al., 2017). The question is, have we reached that stage? Various efforts have been made and planned to produce high quality human resources from the national education system (Kementerian Pendidikan Malaysia, 2013). Despite many changes that have been made, the problem of students' weakness in science subjects and the decreasing number of students pursuing science still remains unresolved (Meerah, 1998; Saidin, Halim, \& Yahaya, 2015).

Scientific learning through inquiry needs to be done so that various scientific skills can be practiced while engaging in practical activities. This can be achieved through 7E Inquiry approach. In order to see the extent of each inquiry step that is conducted; a detailed observation by other peer teachers is needed. This inquiry learning can be well accomplished if the teachers can collaborate in planning the lessons and teaching processes in the classroom, then make a reflection on the development of students' learning in the classroom. Therefore, this study is conducted to explore the development of students' learning in science subjects based on 7E inquiry learning model through Lesson Study approach from the point of: Elicit, Engage, Explore, Explain, Elaborate, Evaluate and Extend.

\subsection{Science Learning through Inquiry Approach}

In the context of Malaysia's education system, science is one of the required subjects for all students from elementary to middle school level. Science education aims to produce students' thinking capability in order to be able to think systematically, analytically, critically and logically, have the problem-solving skills, capable of applying scientific knowledge in life and being able to see the universe from a real perspective (Bahagian Pembangunan Kurikulum, 2014). However, reports from Trends in International Mathematical and Science Studies (TIMMS) and Program for International Student Assessment (PISA) assessments show a disturbing and significant decrease in achievement of students in both Science and Mathematics assessment. Scores obtained for both subjects are below the international average score.

Recognizing the fact that pupils in Malaysia are still inefficiently applying and analyzing scientific knowledge, changes in curriculum and teaching aspects have been made by focusing on the science process and its use in the real world. Science curriculum should encourage active learning, inquiry, problem solving, cooperative learning and other learning methods that can motivate students to study science (Chiang, Yang, \& Hwang, 2014). Children should be given a varie- 
ty of opportunities to gather, organize and classify, make observations, write notes and draw diagrams, as well as making interviews and surveys (Rutherford, 1990).

Inquiry approaches is recognized to help to improve understanding of science concept. Inquiry activity contributes to the process of receiving new knowledge through meaningful learning (Arthur, 2005; Edelson, Gordin, \& Pea, 1999; NikSaleh \& Saleh, 2012). Through inquiry learning, the students have the opportunity to develop scientific investigative skills, although different discipline of science uses different methods of investigation and evidence (Edelson et al., 1999; Chiang, Yang, \& Hwang, 2014). The usual inquiry teaching model in school is the $5 \mathrm{E}$ teaching model of engage, explore, explain, elaborate and evaluate. However, the latest development of inquiry model that is 7E learning model has been more systematically developed at the beginning and in the end of the inquiry process, but it is rarely used. This model is said to be able to extend learning objectives and enhance teacher's creativity in planning students' learning activities (Coldburn, 1997; Balta \& Sarac, 2016). The 7E model contains seven phase of learning that are elicit, engage, explore, explain, elaborate, evaluate and extend. The use of inquiry model in the teaching process helps teachers to ensure that the inquiry process can be implemented properly.

Undoubtedly, the inquiry learning approach gives many advantages and benefits to the students. Therefore, the focus and attention should be given to students' activity. In fact, each student has its own diverse and distinctive intellectual intelligence to accept, respond and use stimulus in the learning process. Careful observation of the way students learn can be done by inviting other teachers to observe the development of students learning during the teaching and learning process. The Lesson Study approach provides space to observe the teaching and learning process.

\subsection{Lesson Study Approach in Learning Process}

The term Lesson Study comes from Japanese word, "jugyokenkyu" which is a combination of two words, "jugyo" means lesson, and "kenkyu" which means study (Abdullah \& Mahamod, 2017; Arani et al., 2017; Fernandez \& Yoshida, 2004). Therefore, Lesson Study is a study on learning process in the classroom. It is a teacher professional development program that forms a consistent and systematic learning community among teachers to enhance individual potential of the teachers and also the group members. Through the practice of Lesson Study, teachers examine learning process through collaborative planning and observation aiming towards developing their teaching quality in order to have a positive impact on students' learning aspects (Iksan et al., 2014; Iksan, Zakaria, \& Daud, 2014; Mahmudi, 2009).

Lesson Study in the context of education in Malaysia consists of four steps: identifying problems and goals, planning the lessons, implementing the teaching and finally reflection (Kementerian Pelajaran Malaysia, 2011; Iksan et al., 2014; 
Iksan, Zakaria, \& Daud, 2014; Rashed et al., 2017). The first step is to determine the teaching objective by studying the curriculum goals and reviewing the syllabus. This set of objectives should be appropriate and consistent with the level of students' learning so that the effectiveness can be seen. The second step is to plan and build a daily lesson plan. In the Lesson Study process, teachers need to collaborate to plan the teaching so that they can fulfill the best learning process for the students (Fernandez \& Yoshida, 2004). This process requires members of the Lesson Study group to select a topic or sub topic for that particular subject. Typically, the members of this community group consist of the members of that subject committee.

The third step is to carry out the teaching and observation. A teacher from the Lesson Study group will perform a lesson in the actual classroom based on a shared lesson plan. Other Lesson Study members act as observers and examine the teaching process as they better understand the contents of the lesson plans that have been prepared together. However, other teachers are also encouraged to watch together in the open classroom. Keep in mind that the primary focus of this observation is on students' learning and not focusing on the teacher. The next step is to evaluate the teaching reflection in the form of discussions (Abdullah \& Mahamod, 2017) about the strengths and weaknesses of the implementation of the inquiry through 7E model. This reflection session is professional and any criticism or comment is aimed at improving the teacher's professionalism (Iksan \& Rahim, 2017).

Lesson Study is considered to be an appropriate approach in the teaching and learning process as it not only enhances the professionalism of teachers but also able to boost students' excellence at the same time. If viewed from the aspect of teaching process in the Lesson Study itself, it is a form of study or research on the teacher's teaching process as well as the student's learning that takes place simultaneously in the classroom. In addition, the main objective of Lesson Study is to look at a larger scope of the teaching session by doing careful analysis of how the students accepts the teaching of the teacher and then use that knowledge to improve future teaching session (Cerbin, 2012).

Teaching and learning of science based on inquiry is very relevant because it combines all of the science process skills. However, to measure the effectiveness of its implementation in class is still a challenge to educators and students. Therefore, Lesson Study approach is suitable to be adopted for this purpose as a community of professionals such as teachers, principals and academician can work together for a specific purpose of enhancing certain lesson. In this study, students' science process skills can be observed by the professionals during the lesson of life process in animal topic, which was previously planned collaboratively by a group of teachers. After the lesson was implemented, the group of professionals would discuss the outcome of lesson during the open class. This way, the effectiveness of inquiry-based learning can be observed and direct impact on students' learning could be thoroughly discussed in the reflection ses- 
sion. Therefore, lesson study provided an opportunity for teacher to assess and reflect their lesson in the classroom, not just based on students' achievement in the examination or test.

\section{Methodology}

This study involved five Science teachers, 31 students (Year 5 or 11 years old) and eight observers. Prior to the teaching process, a group of Lesson Study communities were formed which involved the teachers of science committee. The community groups have been doing discussion on 5 and 7 January 2016 in order to produce a daily lesson plan for the "Animal Life Process" topic. In this discussion, members of the Lesson Study group determined the activities and teaching aids that are appropriate for the purposes of teaching science based on 7E inquiry. This teaching and learning session is divided into seven phases of learning namely the elicit phase, engage phase, exploration phase, explanation phase, evaluation phase and extend phase.

Before the open class was conducted, all observers were given lesson plans that were planned by the community group for the topic of "Animal Life Process". The teaching session was held on January 11,2016, where the open observation was conducted in which there are six teachers and five outside observers. All eleven observers comprise of Science teachers, school administrators and outside observer. Researchers were also directly involved as one of the members in the Lesson Study community group and did the observation. Each student's behavior was noted in the form provided (containing 7E inquiry steps: Elicit, Engage, Explore, Explain, Elaborate, Evaluate and Extend). Video footage at certain points was also recorded during teaching and learning sessions to facilitate the data collection process. This video could be viewed repeatedly so that the data collection process could be done in depth. Researchers also provided several sets of voice recordings for student groups' discussion which aimed at assisting data collection in terms of conversation and questioning among students throughout the teaching and learning process.

Participants of the study which involved year five students were exposed to inquiry-based science learning activities during the learning session of "Animal Life Process" topic. All behaviors, communication, gestures and conversations were observed during the open-class observations based on the steps in the $7 \mathrm{E}$ inquiry learning model. All the observation information undertaken by the observers involved including the Lesson Study group members of the science committee was recorded in a special observation form specifically prepared for this study. Each of the data and information collected is important to be discussed during the reflection session as soon as the open class teaching and learning process ends.

The reflection session was held in the headmaster's room to discuss the newly completed teaching session. This reflection session was headed by the headmaster as the moderator, followed by the teacher who was teaching as well as other observers to comment on the reflection during the observation. Besides observa- 
tion and reflection sessions, researchers also conducted interviews with three science teachers who were the members of the Lesson Study community.

\section{Findings and Discussions}

Inquiry learning is especially emphasized in science learning. Usually, teachers carry guided inquiries where students have been provided with materials and equipment for the experiment. The experimental procedures were also given to the students through practical books. Teachers guided the students to do the experiment from start to finish. Teachers made sure that the experiments are carried out as best they can, according to the specified steps. In fact, teacher's guidance does not give students the opportunity to explore the inquiry learning optimally. Thus, students' skills in experimenting have not been identified yet.

The lesson study approach emphasizes on what the students do in the classroom. In this study, the teacher would like to identify how far the inquiry process can be done as best as possible using the 7E inquiry approach. This discussion will highlight students' activities in each 7E inquiry phase that they experienced.

\subsection{Elicit-Introduction}

The elicit phase is the phase to uncover the existing knowledge of the students and associate them with the topics to be learned. In this phase, the teacher strives to introduce new knowledge that will be learned by asking students to recall the topics they have learned before. This step is important to provide students with the existing knowledge in order to build a strong basic concept before the teacher teaches the next level. For "Animal Life Process" topic, the existing knowledge learned about this topic is "Animal Growth" topic introduced to students during Year 2. Teachers try to bring continuity to this topic by showing animal-related video at the beginning of the learning session.

Teacher plays her part by giving students experience about the world of animals through video observations obtained from YouTube at the link, https://www.youtube.com/watch?v=OjKltoK1LlY. Students are given observation skills during this phase. The quote of the teacher giving instruction to the student to observe the video is as follows: "Ok... sit down first, look at the front... watch carefully... please watch it... (video show from YouTube)" (VTP/7-9). Teachers give a few minutes for the students to individually experience and evaluate the video content that they have just watched.

Both of these activities were carried out in the elicit phase to provide basic introduction to the material that would be associated with the next lesson. After providing the material that can be the basis of knowledge, it is easy for the teacher to move to the next phase which is the engage phase.

\subsection{Engage}

This phase provides the space for students to think more deeply about the mate- 
rials that the teacher gives in the elicit phase. In this phase, teachers have the opportunity to stimulate students' thinking and guide them towards the expected understanding. The purpose of this phase is to motivate and make the students focus on the new topic to be introduced.

The result of the observation showed that the teacher used questioning technique to give the students opportunity to participate in the teaching. Teachers uncover the existing knowledge of the students through the seemingly simple and concise queries but are actually essential to gauge the initial impression on students' basic knowledge on the subjects to be learned. The following learning dialogue presents a series of teacher's queries to the students to encourage them to think critically:

Teacher: Where was the penguin sat on?

Student (R): Ice...

Teacher: Then, what it did... what it saw?

Student (R): It saw a whale...

[VTP/42-45]

Referring to the situation of teacher's questioning in the above verbatim of the teaching, the teacher tries her best to encourage students to think by looking at the way the teacher is asking question. For example, the teacher asked what the penguin did, "Then, what it does?" However, there is no response from the students, which makes the teacher change her question to, "what did it see?" Then the students give an answer, "it saw whales...". In this situation, it is found that the teacher's questioning technique is very helpful in promoting student's idea triggering. Spontaneous question processing is also seen as essential to be mastered by the teacher when the development of students' learning does not show the desired response. When students are able to respond well then it would be easier for the teacher to proceed to a deeper level of learning.

\subsection{Explore}

In this phase, students were given the opportunity to utilize their senses as much as possible to explore the concepts they learned. In this case, students interact with the environment such as the use of a model or natural object so that they can observe and investigate the question or phenomenon that occurs.

Based on the verbatim analysis of the teaching, it is found that students are trying to obtain and use relevant information in finding answers to the given situation. In the concept of "animal life concept", students are given the opportunity to explore the ways animals protect themselves when threatened with danger or when facing enemies.

The following quote shows the moments of students' discussions in the process of finding and exploring the appropriate information.

Faris: To frighten other animals... you see it right... it passed by and then take the wooden stick... it is scaring (other animal)... 
Kartigesan: (while referring to textbooks) Faris, this is the answer... Animal such as anchovies stays in a group. It's the same with elephants. This is a group... that's a group... That's right? This is the same...

[VTP/107-111/K. Faris]

Students explore information by talking to each other while referring to the material for their group discussions.

\subsection{Explain}

At this stage, students recognize the terms related to the new concepts being studied. Students report their findings and discovery to the other students in the classroom. Teachers also provide opportunities for the students to mention, explain, and introduce concepts or terms as well as make conclusions from the exploration phase. In this case, the teacher develops students' communication skills by asking the students to explain what they have learned.

Based on the observations, there are students who seem to be confident in sharing their search results. However, there are also students who seem to be marginalized among them where they are afraid to express their opinions.

The following quote shows communication between students in explaining to other friends in the same group:

Krish: The special features found on the rhinoceros are... the horns that are...

Ezlin: we forgot to add... big... body... and hard.

Ezlin: It's ok... At least we did our best.

Krish: Ok... (Smile)... Horns... which is hard and sharp... full stop.

[VTP/435-440/K. Ezlyn]

Referring to the students' discussion above, this shows that the students are building new information about the protection properties of a rhinoceros based on videos observations and references in textbooks that occur simultaneously. The communication between them also explains that girls are more careful when characterizing an object or things being observed.

\subsection{Elaborate}

Next, students are given a chance to think more deeply about the concepts they are learning and apply the concept to a new context. In this phase, students are trained to explore in more detail their understanding based on the concepts learned through activities such as problem solving. To get more detailed information, students engage in oral questioning.

The oral questioning activity in learning process gives good demonstration on students' development in scientific inquiry learning. This oral questioning can be categorized into two that are oral questioning from teacher to students and oral questioning among students. The following quote illustrates the situation of oral questioning in understanding the concept of 'diversity of protection features 
for animals'.

Teacher: What's that lizard did? What's it doing? What it can do?

Ezlyn: Haa... it can shed its tail...

Teacher: Haa... did it enjoy shedding its tail?

Student (R): Nooo...

Teacher: When the enemy touches it... Then it will...

Student (R): Shed it...

[VTP/482-487/K. Ezlyn]

The teaching verbatim in both situations is the example of oral questioning of the teacher to the students. The findings of the oral questioning techniques used by the teacher is aiming to encourage students to think critically because sometimes students are unable to see a given situation from different perspectives if not encouraged by others. Based on the quote of the teaching verbatim, the teacher is actually trying to guide the students to differentiate between the special protective features of the animal and how the animals use that feature. This process of questioning not only encourages the inquiry nature of the students but also train them to be more focus on their thinking (Nuangchalerm, 2014; Tan \& Lim, 2014).

\subsection{Evaluate}

At this stage, formative evaluations are conducted from the "procurement" stage and the assessment covers the aspects of investigation design, data interpretation, or further action by questioning, which will indicates the level of students' development.

Assessments made during the evaluation phase are based on low-level thinking skills that are simply examining the understanding and the students' ability to remember the things they acquired throughout the learning experience. Questions provided by the teachers also do not require students to do long and complicated thinking.

\subsection{Extend}

At the extend phase, students are trained to develop learning outcomes and apply them in the context of daily life. Therefore, it is hoped that students will try to improve their new knowledge in a structured and deeper way until they are able to link these concepts into different or new contexts.

In this phase, teacher tries to give space for students to think at a fairly high level. Assessment questions given by the teacher during the extend phase are said to have high-level thinking characteristics as it requires students to apply and use the knowledge in new situations, analyze and dissect ideas to components in order to understand the inter-component relationships as well as make judgments and decisions based on specific criteria.

In this extend phase; pupils are required to make a sketch of their imaginative animals with special protective features according to their creativity and imagi- 
nation. After learning about the protective features of 15 species of animals, the teacher feels that it is appropriate to expose students to a higher level of thinking by envisioning an idea of their imaginative animal. Undoubtedly, this final activity is quite challenging for all students regardless whether they are intelligent or weak. However, the teacher as a loyal mentor has given some guidance to the students at the beginning of the activity to facilitate their thinking process.

Teacher: Yes anything... the animal you created... if you want it to have the head of a deer and the crocodile's foot... you can. Whatever you imagine... just draw it... Oops, not draw... just sketch it... You know the difference between drawings and sketching, right... this is not an art class.

[VTP/655-658/PnRozyla]

The science teacher did provide some examples of ideas that the students can use such as their favorite deer-headed animals with very strong studded horns but with a crocodile foot for a more adorable illusion. But it all depends on the creativity of the student to think about it. It is arguably therefore a major feature that encourages the development of student inquiries which was observed during this extend phase that is higher level thinking skills or HOTS.

Therefore, it can be said that not all seven phases of this inquiry are easy to apply by the teacher as planned. Elicit phase and extend phase are two phases that are hard to be studied and observed. The elicit phase is considered to be difficult because the observed characteristics are almost identical to the engage phase that appear next sequentially. While the extended phase challenges teachers to teach because of the higher level of learning and cannot be fulfilled by the students. However, the inspiration for the use of 7E model actually gives more opportunities for the students to clearly highlight the features of inquiry learning in the classroom.

\section{Conclusion}

In conclusion, inquiry learning through the $7 \mathrm{E}$ inquiry approach was demonstrated by the teacher throughout this lesson. Using this approach, students' leaning was developed gradually through the seven steps mentioned. Through these steps, students' prior knowledge is elicited and then the teacher developed their knowledge through various activities and questioning. At the earlier stage, lower order thinking skills are developed as the foundation for teaching higher order thinking skill in the final activity. From the results and reflection, inquiries that students did in the class are observing, questioning, obtaining information, answering, and communicating. They are also engaged in both lower and higher order thinking. Therefore, this study showed that lesson study approach can be an alternative for the teachers to plan the integration of inquiry in learning and further evaluated by other teachers, academicians and professionals to improve the inquiry-based lesson so that it could be carried out successfully in the context of improving students' learning. 


\section{Conflicts of Interest}

The authors declare no conflicts of interest regarding the publication of this paper.

\section{References}

Abdullah, N. A. E. \& Mahamod, Z. (2017). Designing Teaching and Learning of Malay Language through Lesson Study Based Approach. International Journal of Current Research, 9, 48188-48197.

Adnan, M., Ayob, A., Tek, O. E., Ibrahim, M. N., Ishak, N., \& Sheriff, J. (2017). Memperkasapembangunan modal insan Malaysia di peringkatkanakkanak: Kajiankebolehlaksanaandankebolehintegrasianpendidikan STEM dalamkurikulum PERMATA Negara. [Enhancing Malaysian Human Capital from Early Childhood: A Study in the Feasibility and Integratability of the STEM System in the PERMATA Negara Curriculum.] Geografia-Malaysian Journal of Society and Space, 12, 29-36.

Arani, M. R. S., Shibata, Y., Sakamoto, M., Iksan, Z. H., Amirullah, A. H., \& Lander, B. (2017). How Teachers Respond to Students' Mistakes in Lessons: A Cross-Cultural Analysis of a Mathematics Lesson. International Journal for Lesson and Learning Studies, 6, 249-267. https://doi.org/10.1108/IJLLS-12-2016-0058

Arthur, D. (2005). The Effect of Inquiry-Based Instruction on Student's Participation and Attitudes in a Third Grade Science Classroom. Orlando: University of Central Florida.

Bahagian Pembangunan Kurikulum (2014). Kurikulum Standard SekolahRendahDokumen Standard Kurikulum Dan PentaksiranSains Tahun Lima. Putrajaya: Kementerian Pendidikan Malaysia.

Balta, N., \& Sarac, H. (2016). The Effect of 7E Learning Cycle on Learning in Science Teaching: A Meta-Analysis Study. European Journal of Educational Research, 5, 61-72. https://doi.org/10.12973/eu-jer.5.2.61

Cerbin, B. (2012). Using Classroom Inquiry to Improve Teaching and Learning. Virginia: Stylus Publishing.

Chiang, T. H. C., Yang, S. J., \& Hwang, G. J. (2014). An Augmented Reality-Based Mobile Learning System to Improve Students' Learning Achievements and Motivations in Natural Science Inquiry Activities. Educational Technology \& Society, 17, 352-365.

Coldburn, A. (1997). Implementing the Learning Cycle. The Science Teacher, 64, 30-33.

Edelson, D. C., Gordin, D. N., \& Pea, R. D. (1999). Addressing the Challenges of Inquiry-Based Learning through Technology and Curriculum Design. Journal of the Learning, 8, 391-450. https://doi.org/10.1080/10508406.1999.9672075

Fernandez, C., \& Yoshida, M. (2004). Lesson Study. New Jersey: Lawrence Erlbaum Associates.

Iksan, Z. H., \& Rahim, M. B. (2017). Reflection on Teaching and Learning of Mathematics through Lesson Study and Video Critique. Advances in Social Sciences Research Journal, 4, 50-63. https://doi.org/10.14738/assrj.41.2499

Iksan, Z. H., Nor, S. N. A. M., Mahmud, S. N., \& Zakaria, E. (2014). Applying the principle of "Lesson Study" in Teaching Science. Asian Social Science, 10, 108-113. https://doi.org/10.5539/ass.v10n4p108

Iksan, Z. H., Zakaria, E., \& Daud, M. (2014). Model of Lesson Study Approach during Micro Teaching. International Education Studies, 7, 253-260.

https://doi.org/10.5539/ies.v7n13p253

Kementerian Pelajaran Malaysia (2011). Lesson Study: Pembelajaran Melalui Amalan 
Kolaboratif Guru. Kuala Lumpur: Bahagian Pendidikan Guru, KPM.

Kementerian Pendidikan Malaysia (2013). Pelan Pembangunan Pendidikan Malaysia 2013-2025 (Pendidikan Prasekolahhingga Lepas Menengah). Putrajaya: Kementerian Pendidikan Malaysia.

Kementerian Sains Teknologidan Inovasi (2010). The Public Awareness of Science and Technology. Malaysia: Malaysian Science and Technology Information Centre (MASTIC).

Mahmudi, A. (2009). Mengembangkan Kompetensi Guru Melalui Lesson Study. Journal Forum Kependidikan, 28, 1-10.

Meerah, T. S. (1998). Dampak Penyelidikan Pembelajaran Sains Terhadap Perubahan Kurikulum. Bangi: Penerbit Universiti Kebangsaan Malaysia.

NikSaleh, N. Z., \& Saleh, S. (2012). The Effect of Inquiry Discovery Approach towards Student Achievement in the Subject of Chemistry. Asia Pacific Journal of Educators and Education, 27, 159-174.

Nuangchalerm, P. (2014). Inquiry-Based Learning in China: Lesson Learned for School Science Practices. Asian Social Science, 10, 64-71. https://doi.org/10.5539/ass.v10n13p64

Rashed, Z. N., Razak, S. R. A., Shahidan, N., Razali, A. S. M., \& Iksan, Z. H. (2017). Pengintegrasianilmuaqlidannaqlimelaluipendekatan lesson Study di Maahad Tahfiz Sains Negeri Selangor. e-Journal Penyelidikan Dan Inovasi, 4, 30-42.

Rutherford, F. J. (1990). Science for All Americans. New York, NY: Oxford University Press.

Saidin, N. F., Halim, N. D. A., \& Yahaya, N. (2015). A Review of Research on Augmented Reality in Education: Advantages and Applications. International Education Studies, 8, 1-8. https://doi.org/10.5539/ies.v8n13p1

Tan, A. L., \& Lim, S. S. (2014). Science Teacher Education and Science as Inquiry: Promises and Dilemmas. In C. Lin, \& R. Wang (Eds.), Innovations in Science Teacher Education in the Asia Pacific (pp. 147-161). Bingley: Emerald Group Publishing. https://doi.org/10.1108/S1479-3687(2013)0000020009 